\title{
On the African leopard whip snake, Psammophis leopardinus Bocage, 1887 (Serpentes, Colubridae), with the description of a new species from Zambia
}

\author{
BARRY HUGHES \\ 57 Snaresbrook Road, London E11 IPQ, England. \\ E. WADE \\ Middlesex University, Cat Hill, Barnet, Hertfordshire, EN4 8HT, England.
}

\begin{abstract}
SYNOPSIS. An examination of scalation and dentition of specimens in Brussels (IRSN), Tervuren (MRAC) - mostly Bredo collection, and London (BMNH) from Angola, Congo-Kinshasa and Zambia suggests the existence of a species which is neither $P$. sibilans leopardinus of which the type is from Namibia, nor $P$. 'sibilans' [mossambicus] of Congo-Kinshasa and Zambia, but a new species previously unnamed.
\end{abstract}

\section{INTRODUCTION}

Bocage (1887:206) described from Catumbela, Angola a Psammophis (MBL 1798, now destroyed) with a striking reticular pattern on the neck and anterior part of the body as a variety of Psammophis sibilans, a taxonomic treatment later followed by Broadley (1977). More recently Brandstätter (1995, 1996: Fig. 4) has recognised $P$. sibilans as occurring no further south than the northern part of Tanzania and has treated Bocage's variety as $P$. brevirostris leopardinus, following an earlier practice by Broadley (1971). He has followed Broadley (op. cit.) in assigning to this subspecies Zambian specimens showing the same reticular pattern on the neck. However, such a pattern occurs sporadically elsewhere, as in West African specimens of $P$. sibilans (BMNH 1930.6.5.8 from Mogonori, Ghana; 1956.1.5.87 from Ikoyi, Lagos, Nigeria; CM 24636 from Accra; MNHN 1985.442-3 from Ghana; ZMH R04466 from Gana Gana or Segbana, Niger Delta, Nigeria: these have neck bars sometimes interconnected as in leopardinus. Dependence on pattern for identification in a genus whose species are notorious for their variability is unconvincing. In an attempt to find other, more reliable criteria by which to distinguish species of Psammophis, total tooth counts were undertaken and revealed significant differences between specimens of 'leopardinus' from Angola and those from Zambia. Secondly, the Zambian specimens are often of a colour pattern rarely met with elsewhere during the study of several thousand specimens from all parts of Africa and the Middle East. Thirdly, the ventral and subcaudal counts of the Zambian specimens are lower than those from neighbouring localities in Zambia and Congo-Kinshasa. Fourthly, a SEM micrograph of a dorsal scale of a specimen from Ikelenge (Brandstatter, 1995: Fig. 39) differs considerably from those of species assigned to the $P$. sibilans complex. For these reasons, it is thought necessary to coin a new name for the Zambian specimens.

\section{SYSTEMATICS}

Psammophis zambiensis sp. nov. Zambian Whip Snake

Psammophis sibilans, not Linnaeus 1758, Pitman, 1934: 297 (part, Chimikombe specimens only).
Dromophis lineatus, not Dumeril \& Bibron, Laurent 1956:247 Kundelungu male \& female.

Psammophis? sibilans Broadley \& Pitman 1960: 445

Psammophis brevirostris leopardinus Broadley 1971:88; Brandstätter, 1995: 53, Fig. 39 and 1996: 48 (Zambian specimens only); Haagner et al. 2000:16.

Psammophis sibilans leopardinus (Zambian specimens) Broadley 1977:18

Psammophis brevirostris leopardinus Brandstätter 1996:48 (Zambian specimens only)

HOLOTYPE. BMNH 1959.1.1.81 supposedly from 'Abercorn' (now Mbala) area of Zambia, part of the H.J. Bredo collection, sent on from Brussels, but likely to be from Mweru-Wantipa - see discussion (Figs 1-3).

PARATYPES. IRSN 2561,2565-6 of same origin, BMNH 1932.9.9.132-3 from Chimikombe at 4500 ft. (= Chimilombe, Solwezi District); NMZB 10635-6, 10736, 10757 from Ikelenge (Broadley 1991:529); IRSN 2562 from Mambwe; IRSN 2567 and PEM 1438/12 from Mporokoso District (probably Mweru-Wantipa); IRSN 2563 from Mweru-Wantipa, and IRSN 2564 from an unknown source in Zambia; MRAC 18622-3 SERAM, Kundelungu Plateau $1750 \mathrm{~m}$, Congo-Kinshasa (Laurent 1956:247 as Dromophis lineatus).

All specimens, except two (BMNH 1932.9.9.132-3) are female; Haagner et al (2000) have listed two more males as ' $P$. brevirostris leopardinus'.

DIAGNOSIS. Often distinguished by a combination of the reticular body pattern of leopardinus but lacking the higher tooth counts of the latter (Table 1.). A detailed description of colouration, based on 5 specimens, is given by Broadley \& Pitman (1960:445) but can be summed up by saying that they are greenish rather than the usual khaki-brown and the scales heavily edged in black. Unlike associated specimens of $P$.'sibilans' the vertebral 'chain' is more like a stripe, the lighter marking on each vertebral scale being more of a line than a spot; and behind the eyes the head is crossed by three transverse light bars - a common feature in many Psammophis spp. but these are narrow, as in P.angolensis or Dromophis lineatus. Smaller specimens (e.g. Fig. 2-3) are more distinctly marked with greater contrast around the body. As Haagner et al (2000) have 
a

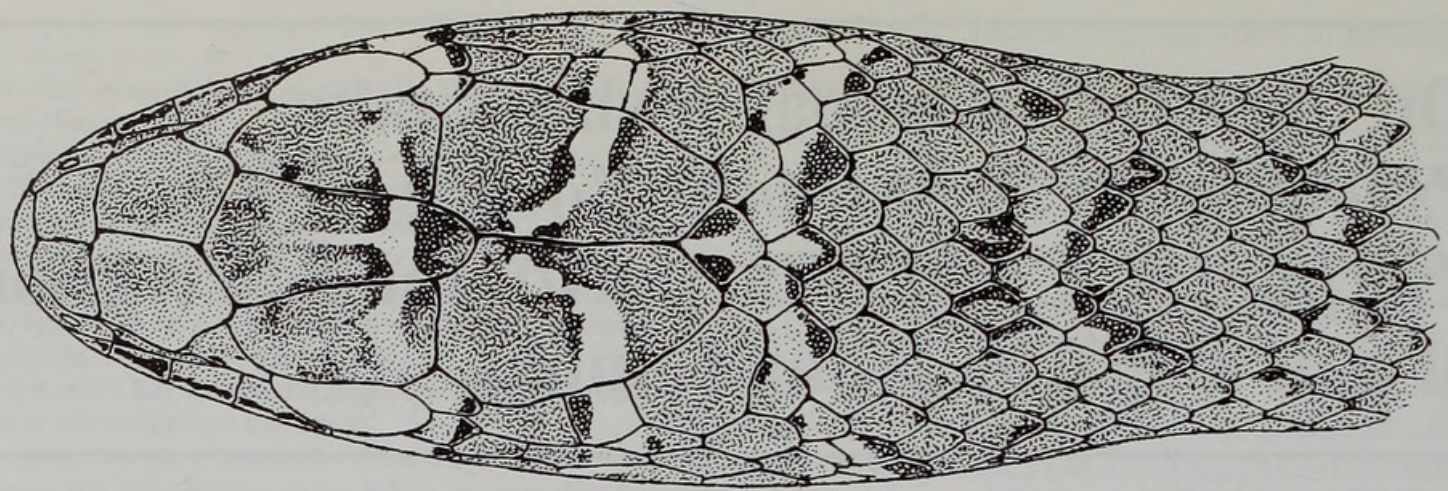

b

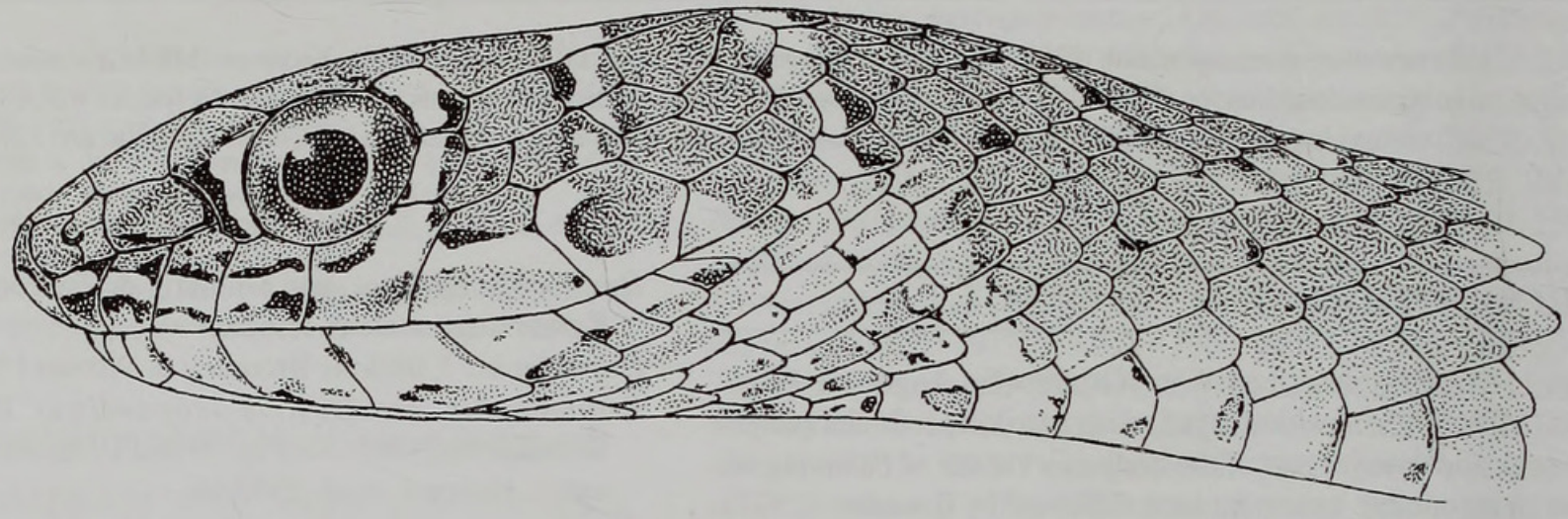

C

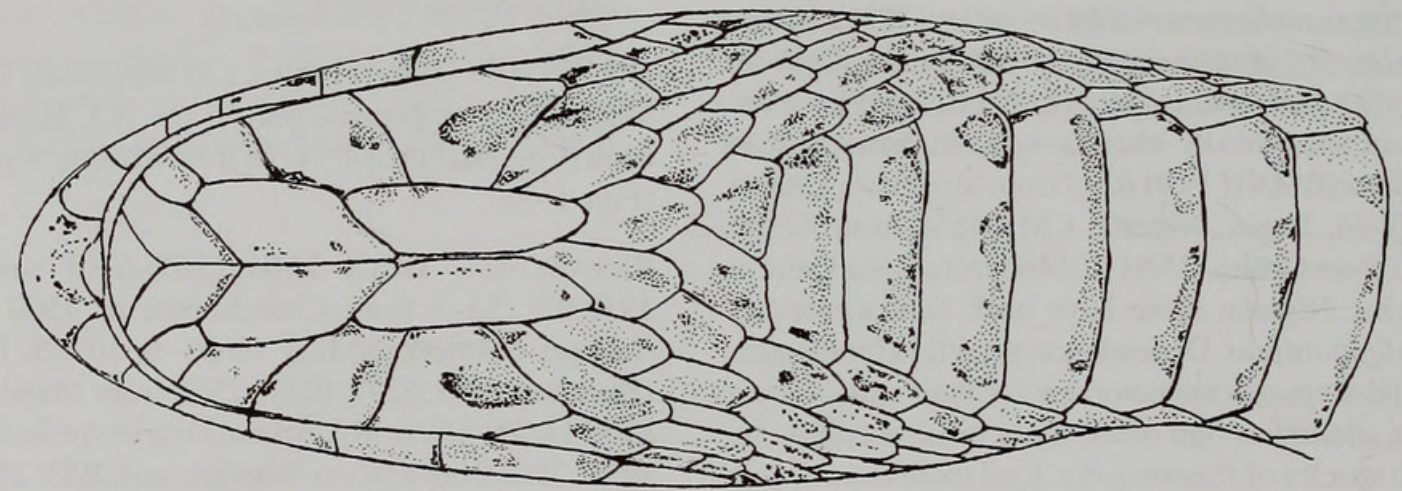

Fig. 1 Head of $P$. zambiensis (adult holotype, BMNH 1959.1.1.81) seen in (a) dorsal, (b) lateral and (c) ventral views.

Table 1 Dentitions - left/right sides

\begin{tabular}{|c|c|c|c|c|c|}
\hline species & museum no. & max.pre- $2 \mathrm{~F}$ & post.dentary & palatine & pterygoid \\
\hline $\begin{array}{l}\text { leopardinus } \\
\text { (Namibia) }\end{array}$ & 1937.12 .3 .166 & $5 / 5$ & $23 / 24$ & $11 / 9$ & $23 / 18$ \\
\hline zambiensis & 1959.1 .1 .81 & $4 / 3$ & $17 / 14$ & $9 / 8$ & $17 / 14$ \\
\hline zambiensis & 10636 & -13 & $14 / 13$ & $8 / 9$ & $13 / 12$ \\
\hline zambiensis & 10736 & $4 / 4$ & $15 / 14$ & $8 / 9$ & $16 / 15$ \\
\hline zambiensis & 10521 & $3 / 3$ & $15 / 15$ & $8 / 8$ & $16 / 16$ \\
\hline zambiensis & 18622 & $3 / 3$ & $16 / 16$ & $7 / 8$ & $14 / 15$ \\
\hline zambiensis & 18623 & $4 / 4$ & $17 / 15$ & $8 / 9$ & $17 / 18$ \\
\hline zambiensis & 1932.9 .9 .132 & $3 / 3$ & $17 / 19$ & $9 / 9$ & $17 / 16$ \\
\hline zambiensis & 1932.9 .9 .133 & $3 / 3$ & $20 / 20$ & $8 / 8$ & $19 / 18$ \\
\hline zambiensis & 1953.1 .2 .15 & $3 / 3$ & $17 / 18$ & $8 / 8$ & $18 / 18$ \\
\hline sibilans & 1953.1 .2 .14 & $3 / 3$ & $19 / 18$ & $8 / 8$ & $16 / 15 ?$ \\
\hline
\end{tabular}



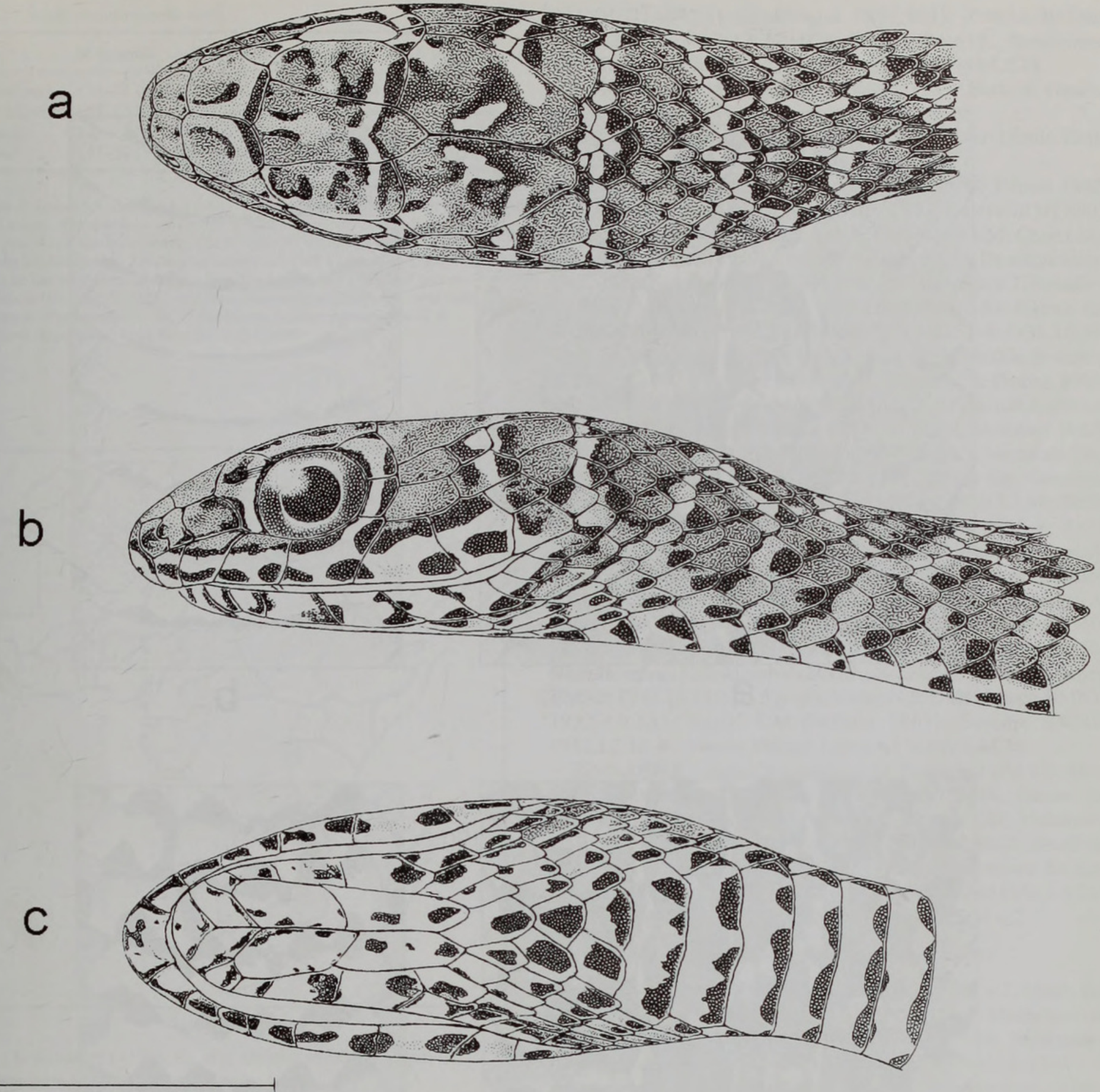

Fig. 2 Head of juvenile paratype P.zambiensis (IRSN 10523) seen in (a) dorsal, (b) lateral, and (c) ventral views.

noticed, the reticular neck pattern is not always present and these specimens are distinguished from 'sibilans' by their lower ventral counts and usually by lower subcaudal counts (Table 2 ).

Brandstatter (1995: Fig. 39) has provided a SEM micrograph of a dorsal scale from a $P$. zambiensis paratype NMZB 10636, and the micro-ornamentation resembles that of Dromophis lineatus (his Fig. 83 ) more than any species of the $P$. sibilans complex.

HABITAT. Unfortunately, no field notes are available for this species, but the fact that many specimens appear to have originated from the Mweru-Wantipa suggests that it requires a marshy habitat like Dromophis lineatus, with which it is sympatric in this area (Broadley \& Pitman, 1959). In the Ikelenge area there there are many suitable dambos and one local specimen had eaten an Eumecia anchietae, a large skink that frequents such places (Broadley, 1991). The
Sanolumba snake had eaten a ranid frog (Haagner et al., 2000).

\section{OTHER SPECIES AND SOURCES OF DATA}

Psammophis leopardinus [only those with numbers seen by $\mathrm{BH}$, those without numbers DGB data or from publications].

ANGOLA - Bella Vista MCZ; Caconda MBL $\times$ 8; Capelongo $\mathrm{AMNH} \times 6$; Catengue SMF $\times 2$; Catumbela MBL lectotype, destroyed; Iona TM; Luanda USNM; Lobito Bay AMNH R506123, R50617-8, and x5; Oncocua, $37 \mathrm{~km}$ NE on way to Otchinzau TM; NAMIBIA - Swakop-Tal, Namib Desert BMNH 1937.12.3.166.

Psammophis 'sibilans', currently treated as P. mossambicus.

CONGO-KINSHASA - Kambore MRAC 2017; Kansenia MRAC 7002, 7639; Kapanza MRAC 9649-50; Kapiri MRAC 7027, 7056- 

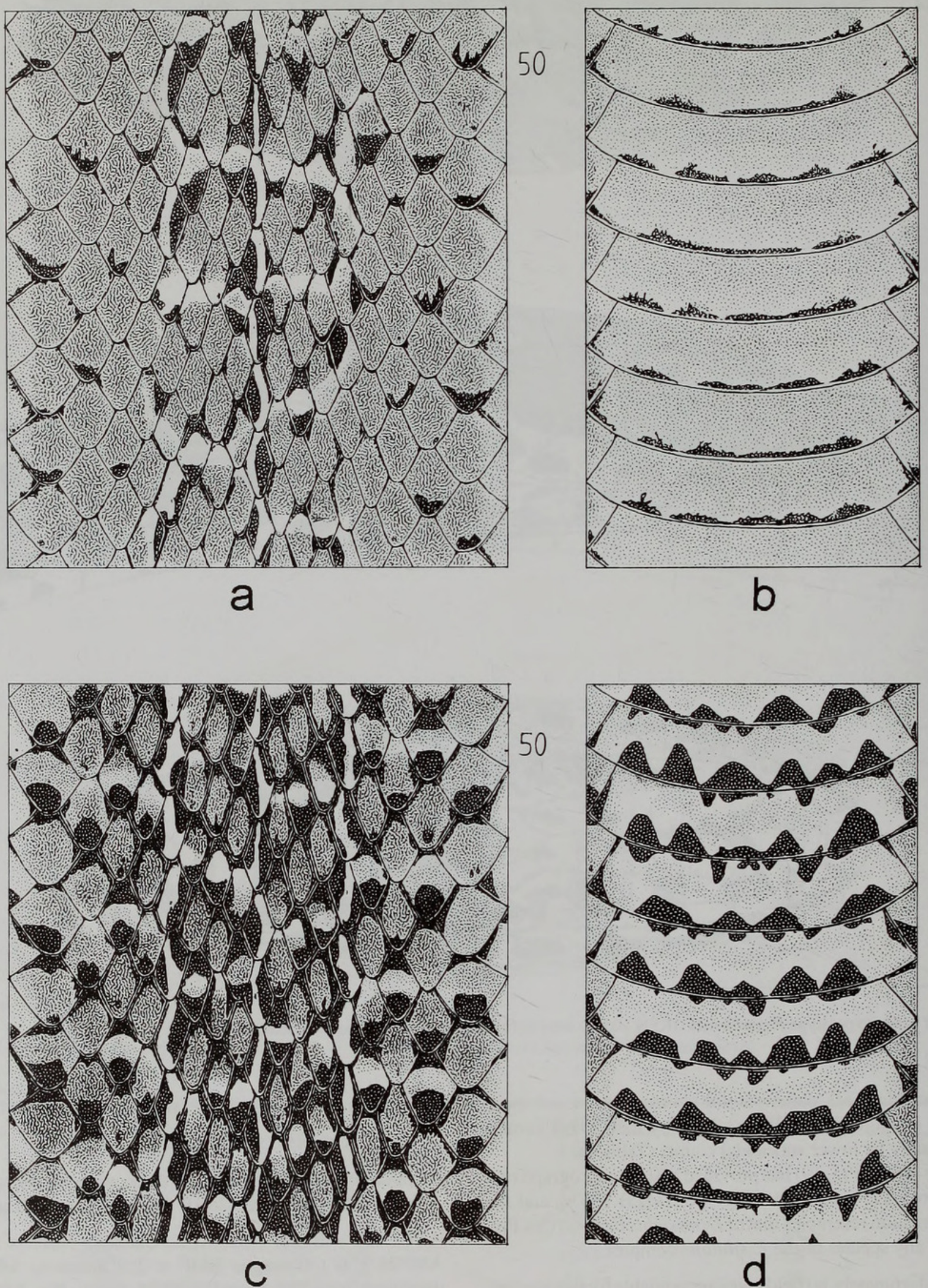

Fig. 3 Stretches of the body of P.zambiensis between ventral scales 50 and 57 seen in dorsal and ventral views. (a, b) Adult holotype (BMNH 1959.1.1.81); (c,d) juvenile paratype (IRSN 10523). 
Table 2 Scale counts (sample size)

\begin{tabular}{lllll}
\hline species & M ventrals & F ventrals & M subc. & F subc. \\
\hline 'leopardinus' & $151-71(9)$ & $151-74(20)$ & $79-104(4)$ & $80-105(10)$ \\
'leop.' refined & $151-65(8)$ & $151-67(16)$ & $79-104(4)$ & $80-105(8)$ \\
zambiensis & $148-61(5)$ & $149-65(17)$ & $80-90(3)$ & $75-86(9)$ \\
'sibilans' & $167-77(32)$ & $167-77(19)$ & $89-103(26)$ & $? 81-100(12)$ \\
\hline
\end{tabular}

N.B. The P. 'leopardinus' data is for Angolan specimens and from Broadley (pers. com.): I suspect that specimens of another species are included and $P$. 'leop. refined' has the data of that species removed. The $P$. 'sibilans' (currently treated as $P$. mossambicus) data is from Zambian specimens so called by Broadley (1971:88) although he has since referred them to $P$. phillipsi (Broadley 1983) and later $P$. mossambicus (Broadley, in prep.), and from Haagner et al (2000) who treat their specimens as $P$. mossambicus. The $P$. zambiensis data incorporates that of $P$ 'brevirostris leopardinus' from Haagner et al. (2000).

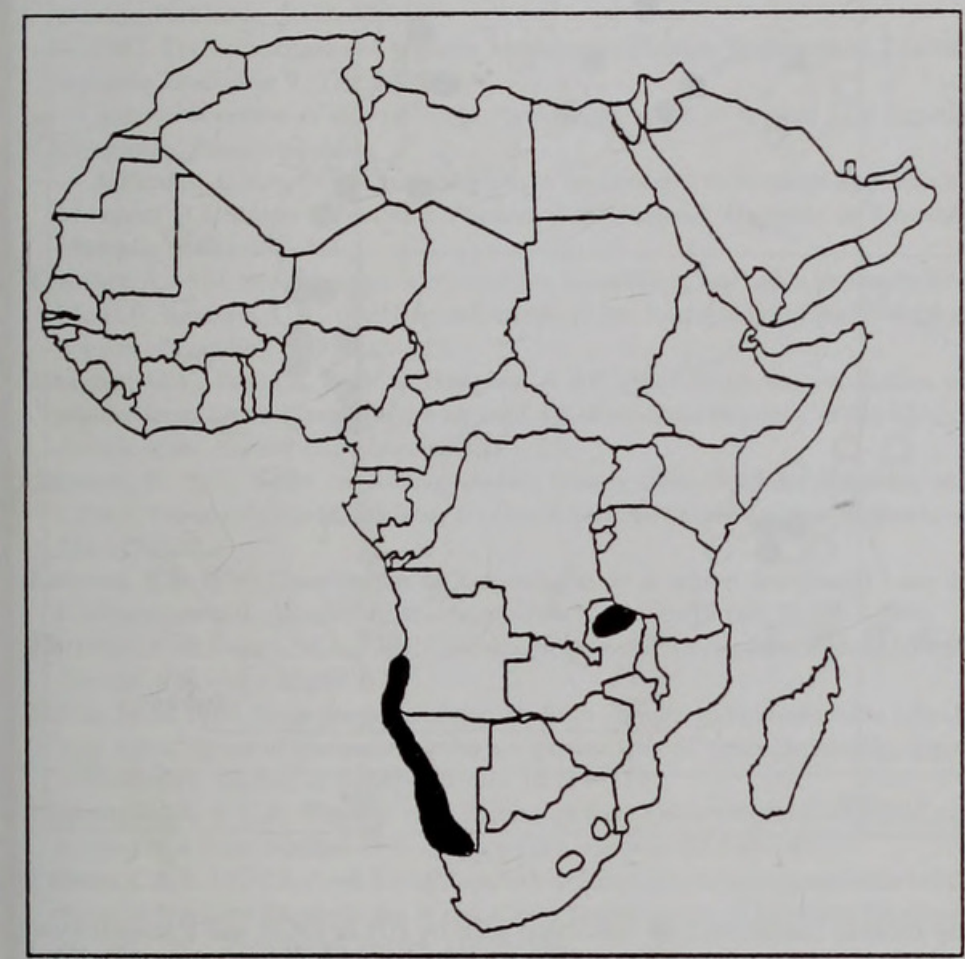

Fig. 4 Brandstätter's (1996, fig. at p. 48) map of the occurrence of Psammophis brevirostris leopardinus.

9, 7061; Kapolowe MRAC 9970; Kasai MRAC 968; Kasenyi IRSN 6861; Lofoi MRAC 598; Lubumbashi [as Elizabethville] IRSN 6310; MRAC 7661, 8378-9, 9397-8; Lukafu MRAC 7187, 71199_ 201, 7217; Luluaborg St Joseph MRAC 2627-9; Luebo MRAC 2996; Lukonzolwa MRAC 2165; Lusambo MRAC 16378, 16381; Merode MRAC 3113; Moero Lake Region MRAC 15323; Musosa IRSN 4780-1; Niambi to Baudouinville MRAC; Pweto MRAC 252, 260, 1980, 1999, 2027; Sandoa MRAC 7935, 7941, 7967-9, 82712, 9854; Tembwe MRAC 4186, 4216, 4237-8;

MALAWI - Chitipa (as Fort Hill) BMNH 97.6.9.135-6; Chiromo BMNH 1959.1.3.37; Chiromo, $20 \mathrm{~km} \mathrm{~N}$ of Mangochi (as Fort Johnston); Fort Johnston BMNH 1926.5.8.49; Kasungu AMNH; Kondowe (=Livingstonia Mission) to Karonga BMNH 97.6.9.1324; Nkhotakhota (as Kota Kota) BMNH 96.12.12.19; Mkanga BMNH 1959.1.3.38; Mlanje River AMNH; $\times 2$; Mtimbuka $\mathrm{AMNH} \times 4$; Mulanje Mt. AMNH; Nchisi AMNH $\times 2$; Nkahta Bay to Ruarwe
BMNH 97.6.9.131 (Boulenger 1897:801); Zomba BMNH 93.10.26.57, 94.2.13.12 (Günther 1894:618, Boulenger 1896:164,1,m), 1933.4.5.2; Zomba Mt BMNH 1948.1.2.28.

NAMIBIA - Old Sangwali (Broadley 1983; Barts \& Haacke 1997).

TANZANIA - Ipiama ZMB 16984; Kingani, nr Dunda ZMB 172777, 17338; Zimba ZMB 23476;

ZAMBIA - IRSN 8834,b-c, 10520, Broadley \& Pitman 1960; ZFMK 18904; Barotseland MNHN 1921.533; Buleya IRSN 8802 (Bulaya of Broadley \& Pitman 1960); Chipangali UM; Chisi Lake (Broadley \& Pitman 1960); Chunga, Kafue N.P. UM; Dumdumwensi UM 20841; Fort Manning BMNH 1962.497; Ikelenge $\times 2$ (Broadley 1991 as P.phillipsii); Kabinda BMNH 1932.9.9.130; Kabwe (as Broken Hill) BMNH 1932.5.3.95-100, 1932.9.9.134-8, 1936.3.6.34, 1959.1.1.96; Kalabo FMNH, UM; Kaputa IRSN 8805,a, Broadley \& Pitman 1960); Kasama IRSN 8832, Broadley \& Pitman 1960; Lachisi IRSN 8830; Lealui MNHN 20.104, 21;533; Lusaka, 100 km SW of ZFMK 18904; Makupa IRSN 8835,a,b; Mambwe IRSN 8804, 8828-9, Broadley \& Pitman 1960; Maskie's, Namwala District BMNH 1932.5.3.95-8. 1932.5.3.101; Mbala (as Abercorn, Broadley \& Pitman 1960) BMNH 1959.1.1.81, 1959.1.1.96; IRSN 8798a-e - 803,a, 8799a-b, 8800-1, 8806-27, 8836-8, 8839 (Broadley \& Pitman 1960 as Psammophis subtaeniatus sudanensis); Mkanda UM; Mporosoko IRSN 8803a-b (Mporokoso of Broadley \& Pitman 1960); Msoro UM (Wilson 1965); Mukupa (Broadley \& Pitman 1960); Muswema IRSN 8833, Broadley \& Pitman 1960; Mweru-Wantipa IRSN 8831, Broadley \& Pitman 1960; Namantombwa Hill, Mumbwa UNZA; Nchelenge, Luangwa Valley BMNH 1932.12.13.231; Ngoma, Kafue N.P. UM; Nsangu BMNH 1932.9.9.131; Sayiri UM (Wilson 1965); Serenje BMNH 1953.1.2.13-6 ; Yacobi Village, Luangwa Valley LACM;

ZIMBABWE - Bari, Chikwakwa UM; Bulawayo UM $\times 3$; Elim Mission, Inyanga UM; Harare (as Salisbury) NMK; Harare (as Salisbury), Borrowdale Brook UM $\times 2$; Inkomo UM; Mabalauta UM; Mazoe (Broadley 1959) BMNH 1902.2.12.96-7; Mondoro UM; Odzi UM $\times 2$; Rugare, Inyanga UM; Umsweswe Bridge, Gatooma UM; Umtali UM $\times 3$ (Broadley 1959) BMNH 1954.1.3.234; Vumba Mt UM $\times 2$; Wankie N.P., main camp $\mathrm{UM} \times 2$.

Psammophis zambiensis (other, non-type specimens)

ZAMBIA - Ikelenge NMZB 10636, and $\times 2$; PEM $\times 7$; Mbala (as Abercorn, Broadley \& Pitman 1960) IRSN 10521-2; Mbala area (as 'Abercorn' but see Discussion); BMNH 1959.1.1.81; Mporosoko (Broadley \& Pitman 1960 as Mporokoso) IRSN 10523; PEM $\times 2$ (Haagner et al 200); Sakeji School PEM $\times 6$ (Haagner et al., 2000).

\section{DISCUSSION}

The many names by which Zambian P.'sibilans' has been known (see above under synonymy) is an indication of the uncertainly which attends identification of specimens of this species complex. The very distinctive colouration of some specimens of $P$. zambiensis attracts attention but it is not reliable in separating this species from other(s) with which it may be sympatric. A letter from Desmond Vesey-FitzGerald to Donald G. Broadley (Broadley, pers. comm.), dated 29 Sept. 1959, suggests that the source of 'Abercorn' specimens is to be doubted: 'I would guess that all these snakes may have come from Mweru-Wantipa in Mporokoso District, where Bredo would have been collecting in the $1943 / 44$ period.' Vesey-FitzGerald (1958) collected long series of $P$. sibilans $[=P$. mossambicus $]$ in 


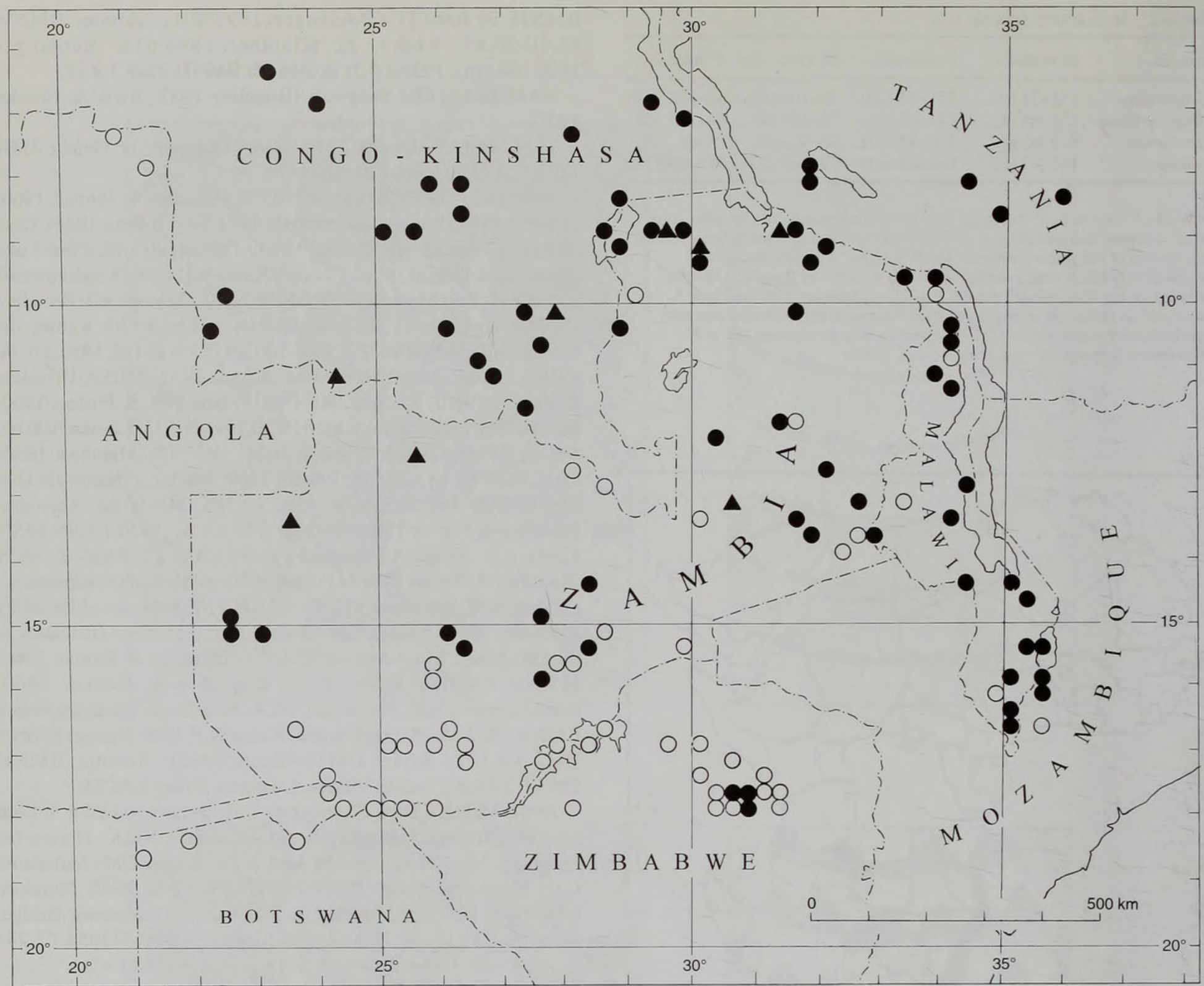

Fig. 5 Map of area of sympatry between $P$.'sibilans' $(\mathrm{O}$, literature ref. which may include zambiensis; $\mathbf{}$ specimen seen by BH or DGB and P.zambiensis $\Delta$ specimens seen). Many records taken from Broadley (1983:146, map 36 of $P$. 'phillipsii', others from an as yet unpublished, revised map (DGB in prep.) which we have been privileged to see. Localities listed by country and quarter degree square (without 'se' prefix); sources indicated when locality is a map plot without name. For locality data see Appendix 1.

Abercorn [= Mbala] District, but none had either the characteristic pattern or low ventral counts of $P$. zambiensis. However, he did record one snake from Chinsali $(10.32 \mathrm{C} 1)$ with only 160 ventrals and 90 subcaudals, which may have been a $P$. zambiensis, but it was apparently not preserved. Only by collecting data on a large number of specimens can the limits of variability become known and consistent differences in meristic data become apparent.

P. zambiensis and $P$. 'sibilans' appear to be sympatric at Mbala (Abercorn) (Fig. 3, se08.31C4) but all of the P. zambiensis specimens so attributed are likely from Mweru-Wantipa (see above), so that true sympatry may occur only at Mporokoso (se09.30), Ikelenge (se11.24a2) Serenje (se13.3061) and near Mchinji (13.32d4). The co-occurrence over such a large distance - more than $600 \mathrm{~km}$ from Ikelenge to Mweru Wantipa without more instances of sympatry suggests the occupation of different habitats.

$P$. zambiensis seems to be distinct from $P$. leopardinus to the south and $P$.'sibilans' (or 'phillipsi') to the north; the true identity of the latter can become clearer only after analysis of specimens from the whole of the Congo Basin and West Africa.

ACKNOWLEDGEMENTS. We are indebted to Donald Broadley for his usual generosity with his data and advice and for the loan of specimens; to curators Charles Myers and Richard Zweifel (AMNH), Georges Lenglet (IRSN, Brussels), Danny Meirte (MRAC, Tervuren), Rainer Günther (ZMB), and Colin McCarthy (BMNH) for similar loans and providing one or both of us with working space and answering our many queries.

\section{REFERENCES}

Barts, M \& W.D. Haacke. 1997. Zur Reptilienfauna der Tsodilo-Berge und Angrenzender Gebiete im NW-Botswana. Teil 2: Sauria: 2 Serpentes. Sauria 19:1521

Bocage, J.V.B. du. 1887. Mélanges erpétologiques. IV. Reptiles du dernier voyage de MM. Capello et Ivens à travers l'Afrique. Jornal de Sciencias Mathematicas, Physicas e naturaes. Lisboa. 10: 201-208. 
Boulenger, G.A. 1896. Catalogue of the snakes in the British Museum (Natural History). 3, 727 p.

1897. A list of the reptiles and amphibians collected in Northern Nyasaland by Mr.Alex Whyte, F.Z.S. and presented to the British Museum by Sir Henry H Johnston, K.C.B., with descriptions of new species. Proceedings of the Zoological Society of London [1897]: 800-803.

1910. A revised list of the South African reptiles and batrachians, with synoptic tables, special reference to the specimens in the South African Museum and descrip tions of new species. Annals of the South African Museum. 5: 455-538.

Brandstätter, Frank. 1995. Eine Revision der Gattung Psammophis mit Berücksichtigung der Schwesterngattungen innerhalf der Tribus Psammophiini (Colubridae; Lycodontinae). Dissertation zur Erlangung des Grades des Doktors der Naturwissenschaften der Mathematisch-Naturwissenschaftlichen Fakultät der Universität des Saarlandes. Saarbrücken. 480 pp.

- 1996. Die Sandrennattern. Die Neue Brehm-Büchkerei 636.. Westarp Wissenschaften, Magdeburg. $142 \mathrm{pp}$

Broadley, D.G. 1959. The herpetology of Southern Rhodesia Part 1. Snakes. Bulletin of the Museum of Comparative Zoology 120: 1-100.

1971. The reptiles and amphibians of Zambia. Puku (6): 1-143.

1977. A review of the Genus Psammophis in southern Africa (Serpentes Colubridae). Arnoldia Rhodesia 8(12): 1-29.

1983, 1990. FitzSimons' snakes of southern Africa. 387 p. Jonathan Ball \& Ad Donker, Parklands, South Africa

1991. The herpetofauna of northern Mwinilunga District, Northwestern Zambia Arnoldia Zimbabwe 9 (37): 519-538

In prep. A review of the species of Psammophis south of latitude $12 \mathrm{~S}$ degrees (Serpentes: Psammophiinae)

\& Pitman, C.R.S. 1959. On a collection of snakes taken in Northern Rhodesia by Monsieur H.J. Bredo. Occasional Papers of the National Museums of Southern Rhodesia (24B): 437-451

Gunther, A. 1894. Second report on the reptiles, batrachians, and fishes transmitted by Mr. H.H. Johnston, C.B., from British Central Africa. Proceedings of the Zoological Society of London [1893]: 616-628.

Haagner, G.V., Branch, W.R. \& Haagner, A.J.F. 2000. Notes on a collection of reptiles from Zambia and adjacent areas of the Democratic Republic of the Congo. Annals of the Eastern Cape Museums 1: 1-25.

Johnsen, P. 1962. Notes on African snakes, mainly from Northern Rhodesia and Liberia. Videnskabelige Meddelelser fra Dansk Naturhistorisk Forening IKobenhavn 124:115-130.

Laurent, R.F. 1956. Contribution à l'herpétologie de la région des Grands Lacs de l'Afrique centrale. Annales du Musée royal du Congo Belge (sér. 8) 48: 1-390

Norton, C.C. \& Peirce, M.A. 1985. Caryospora species from Zambian snakes. African Journal of Ecology 23: 59-62.

Peirce, M.A. 1984. Some parasites of reptiles from Zambia and Indian Ocean islands with a description of Haemogregarina zambiensis sp. nov. from Dispholidus typus (Colubridae). Journal of Natural History 18:211-217

Pickersgill, M. \& C.A. Watson. 1998. Report on the reptiles observed on a field trip to Eastern Africa, October 1996-August 1997. Herptile 23:145-149.

Pitman, C.R.S. 1934. A check list of Reptilia and Amphibia occurring and believed to occur in Northern Rhodesia. In: A report on a faunal survey of Northern Rhodesia pp. 292-312. Government Printer, Livingstone.

Sweeney, R.C.H. 1961. Snakes of Nyasaland. Zomba: Nyasaland Society. 200 pp.

Swynnerton, G.H. 1957. Notes on the fauna. Reptiles. Annual Report of the Game Preservation Department of Tanganyika Territory (1955-6): 28-29.

Vesey-FitzGerald, D.F. 1958. The snakes of Northern Rhodesia and the Tanganyika borderlands. Proceeding and Transactions of the Rhodesia Scientific Association 46: $17-102$

Wilson, V.J. 1965. The snakes of the Eastern Province of Zambia. Puku 3: 149-170.

\section{Appendix 1}

ANGOLA - 17.19d3 DGB in prep. BOTSWANA - 18.21b4 DGB in prep.; c1 DGB in prep. CONGO-KINSHASA - 06.23a4 Merode; 06.24c3 Kapanza; 06.29c4 Tembwe; 07.28a3 Kiambi; 07.29 Niambi to Baudouinville; 07.29b2 Baudouinville; 08.25c3 Kamina; 08.26a2 Kikondja. 08.26c2 Nyonga; 08.28b4 Pweto; 08.28d3 Lukonzolwa; 09.22d3 Sandoa; 09.28b2 Moero Lake region; 10.22a4 Dilolo; 10.26a3 Kansenia; Kapiri; 10.26d3 Kambove; 10.27 Katanga; 10.27a2 Lofoi; 10.27d1 Lukafu; 10.27d2 SERAM, Kundelungu; 10.28b3 Kasenga; 11.26b2 Kapolowe; 11.27c2 Lubumbashi [as Elizabethville] 11.24b1 Sanolumba ; MALAWI - 09.33c2 Chitipa (as Fort Hill); 09.33d1 Misuku Hills; 09.33d4 Karonga (Pickersgill
\& Watson 1998); 10.34a3 Nyungwe; 10.34c1 Kondowe (= Livingstonia Mission); 10.34c3 Nchenachena; 11.33b2 Rumpi; 11.34a3 Nkhata Bay to Ruarwe; 12.34c4 Nkhotakhota (as Kota Kota); 13.32a2 Kasungu; 13.34a3 Nchisi Mt.; 14.34a4 Dedza; 14.35a3 Mtimbuka; a4 Mangochi (as Fort Johnston); 15.35a4 Zomba; b3 Mchenga; c3 Limbe (Sweeney 1961:147); d3 Mlanje Mt.; 16.34b2 Likabula R., Mt Mlanje; 16.35a3 Broadley (1983, as P.phillipsii); b1 Broadley (1983 as P.phillipsii); c1 Chiromo (Broadley 1983 as P.phillipsii); Makanga. MOZAMBIQUE 16.31b1 DGB in prep; 17.35d3 Broadley (1983); 18.33a3 Broadley (1983); 18.34a4 Broadley (1983); 18.35b4 Broadley (1983); NAMIBIA - 17.24c1 DGB in prep.; c2 DGB in prep.; c4 DGB in prep.; d4 DGB in prep.; 17.25c3 DGB in prep.; 18.23b3 Old Sangwali; TANZANIA - 07.31d4 Zimba; 08.31b2 Milepa; 08.35b4 Uzungwa (as Udzungwa Mts); 09.33d2 Ipiama. ZAMBIA - 08.29c4 Mukupa Katandula; 08.29d3 Lake Chisi, Mweru-Wantipa; 08.29d4 Kaputa; 08.31c4 Mbala (as Abercorn); 09.28b2 Molo; 09.29c3 Kawambwa; 09.30a3 Mporokoso; 09.31b2 Mambwe; 10.30c3 Luwingu District; 10.31a2 Kasama; 10.31b1 Nchelenge; 11.24a2 Ikelenge; Sakeji School; 11.31c4 Mpika; Nsangu R.; 12.26b3 Chimilombe (as Chimikombe); 12.27b4 Chingola (Haagner et al., 2000); d1 Lufwanyama Farm (Haagner et al., 2000); d2 Musenga (Haagner et al., 2000); 12.28c3 Kitwe (Haagner et al., 2000); d3 Ndola (Johnsen, 1962); 12.28c1 $24 \mathrm{~km} \mathrm{~W}$ of Mufulira (Johnsen, 1962); 12.30a2 Kabinda, Lukulu R.; 12.32c1 Yakobe (as Yacobi), Luangwa Valley; 12.33a3 Lundaz (Wilson, 1965)i; 12.34c4 Kota Kola; 13.24c1 Kabompo.; 13.25b4 Kasempa; 13.28a2 8km W. of Luanshya.; 13.30a2 DGB in prep.; a3 Katete (Wilson, 1965); b1 Serenje - $P$. zambiensis sympatric with $P$. 'sibilans'; 13.31d2 Msoro; b3 Nsangu River, W of Lavushi River; 13.32a3 Chikowa (Wilson, 1965); b1 Chipangali (Wilson, 1965); b3 DGB in prep.; c2 Kalichero (Wilson, 1965); c4 Sayiri (Wilson, 1965); d1 Chipata (Wilson 1965, as Fort Jameson); d2 Mkanda; d4 near Mchinji (as Fort Manning); 13.33a2 Kasanga; 14.22d3 Kalabo; 14.27c3 Mumbwa; 14.28a4 Kabwe (as Broken Hill); 14.30d1 Kacholola; 15.22b1 Buleya; b4Ndau School; 15.23a1 Lealui; 15.25d4 Ngoma, Kafue N.P.; 15.26a1 Chunga, Kafue N.P.; c2 Maskies; Fort Manning (Wilson, 1965); 15.27d3 100 km SW of Lusaka; d4 Mazabuka; 15.28a4 Lusaka; b3 50 km E. of Lusaka; c2 Balmoral, (Peirce, 1984; Norton \& Peirce, 1985) Chilanga; 15.29c2 DGB in prep.; d2 DGB in prep.; 16.23d1 Kachola (Wilson 1965, as Kacholola); 16.25c3 Machile Forest Station.; c4 Mulanga; d4 Katanda; 16.26c1 Dumdumwensi; c4 Kasusu; 16.27c3 Nansi Farm; d4 Chezia confluence, Kariba Lake; 17.24a3 Katima Mulilo; a4 Wenela base, Caprivi; 17.26a2 Kalomo; c4 DGB in prep.; d4 Ihaha; 17.27b1 Kariba lake, Lulongwe confluence; 18.21b4 Broadley (1983); c1 Broadley (1983); 18.23b3 Old Sangwali; ZIMBABWE - 16.28c4 Lake Kariba, Bumi confluence; d1 Kariba lake, Sanyati basin; 16.29d3 DGB in prep; 16.30b4 Mzarambanitam; c3 Salator Farm, Mkanguru; 16.31d3 Mt Darwin (Broadley, 1959); 17.28c3 Sengwa R.; 17.30a1 DGB in prep.; a3 Sinoia (Broadley, 1959); b1 Msitkwe R., Mutorashanga; c1 Selukwe; c2 Broadley (1983); c3 Kutama (Broadley, 1959);c4 Broadley (1983); d1 Inkomo, d2 Mazoe (Boulenger 1910; (Broadley, 1959); Mt Hampden (Broadley, 1959); d3 Norton (Broadley, 1959); d4 Hunyani (Broadley, 1959); 17.31a3 Broadley (1983); c1 Harare (as Salisbury, Broadley 1959); Borrowdale Brook; c2 Bari, Chikwakwa; c3 Harare (as Salisbury, Boulenger 1910); c4 Melfort (Broadley, 1983); 17.32a3 5 km W of Mutolo Broadley (1983); d2 Elim Mission, Inyanga; d3 Maristvale, Nyanga (Broadley 1983); d4 Nyamaropa, Nyanga (Broadley, 1983); 18.26c4 Broadley (1983); d2 Broadley (1983); 18.27c2 Broadley (1983); 18.32b4 Broadley (1983). 


\section{$2 \mathrm{BHL}$ Biodiversity Heritage Library}

Hughes, Barry and Wade, E. 2002. "On the African leopard whip snake, Psammophis leopardinus Bocage, 1887 (Serpentes, Colubridae), with the description of a new species from Zambia." Bulletin of the Natural History Museum. Zoology series 68(2), 75-81. https://doi.org/10.1017/S0968047002000080.

View This Item Online: https://www.biodiversitylibrary.org/item/127503

DOI: https://doi.org/10.1017/\$0968047002000080

Permalink: https://www.biodiversitylibrary.org/partpdf/78436

\section{Holding Institution}

Natural History Museum Library, London

\section{Sponsored by}

Natural History Museum Library, London

\section{Copyright \& Reuse}

Copyright Status: Public domain. The BHL considers that this work is no longer under copyright protection.

This document was created from content at the Biodiversity Heritage Library, the world's largest open access digital library for biodiversity literature and archives. Visit BHL at https://www.biodiversitylibrary.org. 